\title{
Impact Stories and Testimonies from Diverse Actors in Groundnut Value Chain in Tanzania
}

\subsection{Farmers and Farmer Groups in Remote Communities Share Their Benefits from TL Projects' Investments in Tanzania}

\subsubsection{Farmer Sharing Asset Enhancement Through Groundnut Production}

Adamu, a groundnut farmer from Maugura village, Masasi, shared his success story for being involved in TL projects (Figs. 2.1 and 2.2). "I was taught how to grow the seeds, carry out diagnosis, how to store them, among other things. This year, there are some seeds that I have begun putting on the ground so that I can continue conducting research about them. Naliendele Institute gave me about 20 lines and I am working on all of them. In fact, they have not yet been named. I've just planted them in plots; from plot number one to plot number twenty."

Nyirenda is reaping big from his seed production business. "Last year, I got 90 bags of groundnut from 4 acres, and I sold 47 bags through Naliendele. I sold to other farmers the remaining 43 bags" he said. One bag equals to $42 \mathrm{~kg}$.

Nyirenda does not regret his decision to venture into groundnut seed production. "First, I have six children; two are in secondary school and two are in primary school. I pay their fees from the money I earn in the groundnut business. I have built a good house and bought more land to expand the planting area from the proceeds of the groundnut business as well. Generally, I would say, for me this a self-sufficient business."

Nyirenda, however, appeals to the government to purchase planters on behalf of the farmers as this will reduce the cost of production and increase profits. He also thinks that if a factory is set up for groundnut value addition, farmers like him will not struggle any longer with lack of market.

Groundnut have transformed my Life,-Adamu Nyirenda. 


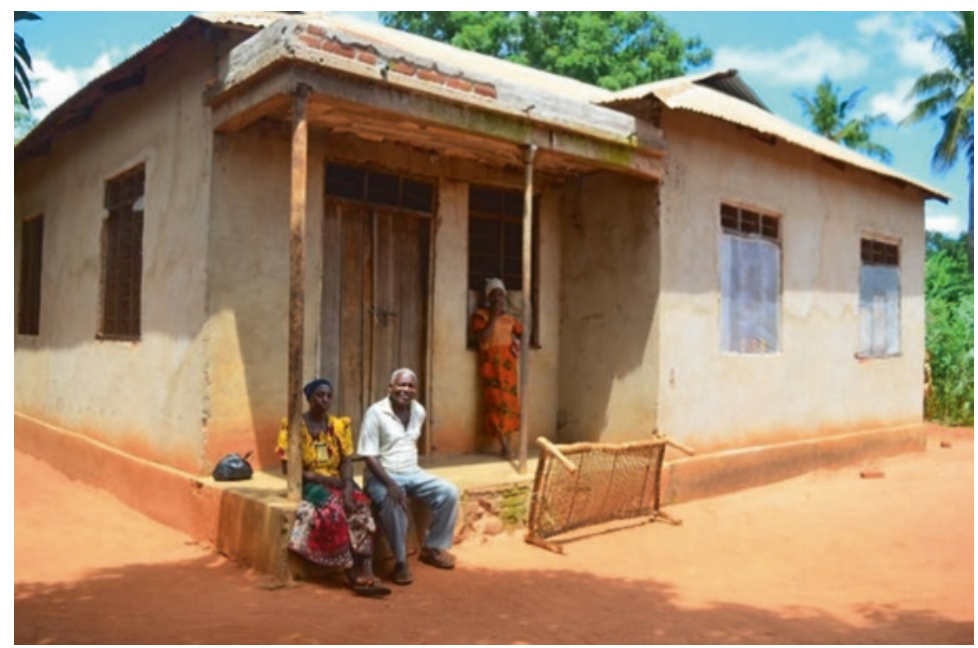

Fig. 2.1 Mr. Adamu Abilah Nyirenda with part of his family outside their house constructed with proceeds from groundnut in Maugura village, Masasi District, Tanzania (Photo: Ndichu J)

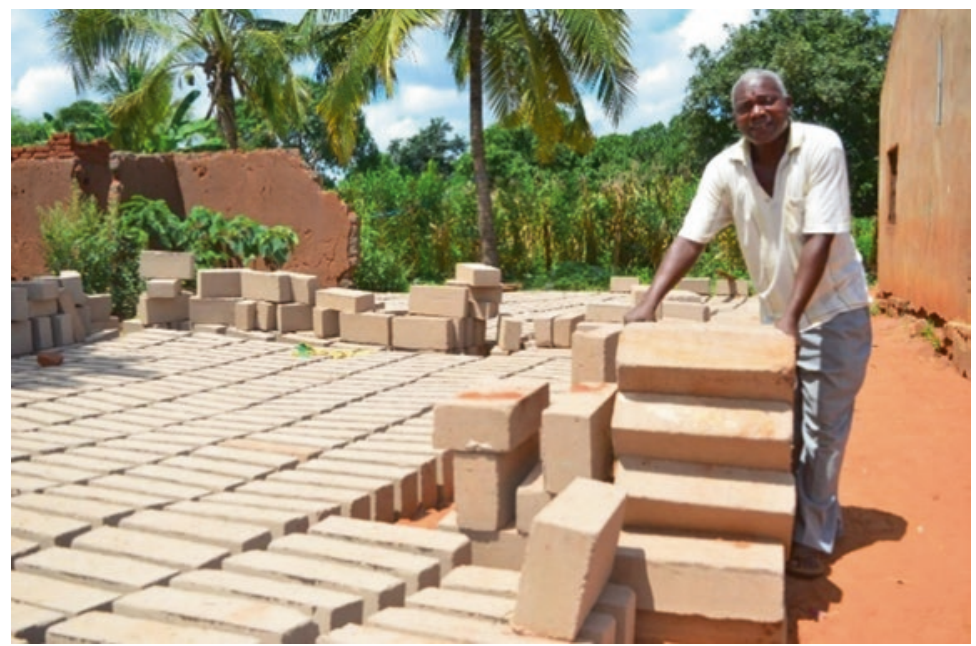

Fig. 2.2 Mr. Adamu Abilah Nyirenda, Maugura village in Masasi District, Tanzania shows bricks he was able to acquire to do more constructions in his homestead, all from groundnut proceeds (Photo: Ndichu J)

In March 2018, we met Adamu Abilah Nyirenda who is now a seed producer at Maugura village in Masasi District. Nyirenda who has been closely working with Naliendele Research Institute says he was fully involved in developing of the Nachingwea variety. 


\subsubsection{Farmer Groups Take Up Groundnut Farming as a Business}

Among different groups sampled, many took up farming groundnut as a business in different regions of Tanzania. The results are impressive as all groups are now reaping big from this business and they are not turning back. Examples of these groups involve:

- Hekima Farmers' Group located in Nzali, Chamwino District, Central Zone. The group has 13 members, 2 men and 11 women, currently doing seed multiplication.

- Jumatuwa Farmers' Group located in Nzali, Ushetu District, Lake Zone. The group has a total of 18 members, 2 men and 16 women.

- Jipemoyo Group located in Kinanga, Kahama District, Lake Zone. The group has 30 members, 14 men and 16 women.

- Upendo Women Group located in Mnanje, Masasi District, in Southern Zone. The group has 25 women.

- Owe Faraja Group located in Mindola, Bahi District, Central Zone. The group has 15 men.

Apart from farming as groups, all of them encourage individual members to plant in their household farms, thereby increasing productivity and multiplying benefits.

We talked to members of these groups and sampled a few different reactions they had to say.

Ms. Anastazia Thomasi Madeje (Fig. 2.3) is Hekima Famers' group secretary. She still vividly remembers some of the teachings they received through Naliendele

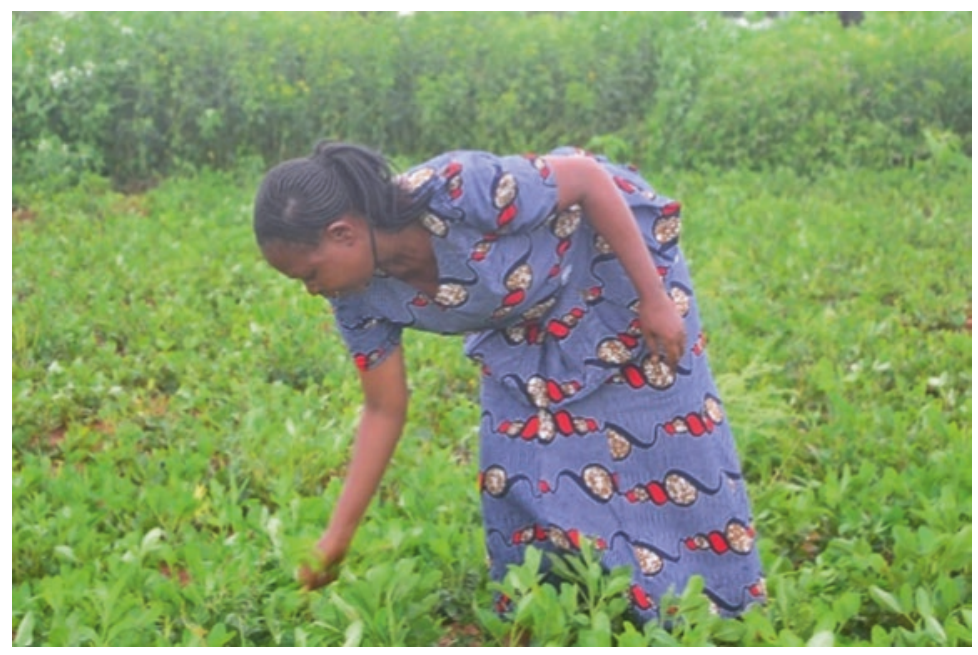

Fig. 2.3 Ms. Anastazia Thomasi Madeje; Hekima Famers' group secretary at the Group's farm in Nzali, Chamwino District, Tanzania (Photo: Ndichu J) 
Institute. "Initially, we used Pendo variety but later this year we were given three other varieties by the Chamwino District Council; Naliendele, Mangaka, and Mnanje. I've planted these three according to the dimensions the agricultural officer directed us. Each seed has its bed, with spaces of up to 50 centimetres from one line to the other, 10 inches from one hole to the next and the size of each bed is 15 meters," she informed us.

Mr. Andera Shoko Kayanda, Secretary, Jumatuwa Farmers' Group (Fig. 2.4), helps us to compare the old groundnut varieties and the new improved ones. "There are several differences; for instance, with Pendo, women say while preparing meals it's easy to mix with vegetables, they are soft, white in colour, have a lot of fat content and are sweet," says Kayanda.

Mr. Francis Paschal, a member of Jipemoyo Group, says through the proceeds they get from selling groundnut seeds, his group has been able to purchase 1 acre piece of land, which is not enough and they have hired 2 more acres (Figs. 2.5 and 2.6). "Our lives have improved," says Paschal. "Groundnut grows fast compared to other crops that we grow. We deal with rice, maize, and groundnut. After planting in November, we can harvest groundnut; at that time maize and rice will still in the ground. This enables us to have cash-flow as we wait for maize and rice to harvest".

Ms. Judith Msonje Masaka, the Chairperson of Upendo Women Group (Fig. 2.7), has also seen the difference between the old varieties that farmers were used to and the new improved varieties they have embraced. "These varieties are big in size and do not require much work during the breakthrough. Last year, I personally ploughed one acre and got fifteen sacks which I sold to improve my life at home," says Masaka.

Owe Faraja Group in Mindola village, Bahi District, is a relatively youthful group (Fig. 2.8). Mr. Stephano Joseph, the group chairperson, reported that they are currently doing trials. "In our 1 acre piece of land, we have Mangaka, Naliendele, Mnanje and an old check variety,” says Mr. Maongezi Mohamedi Hassani, the

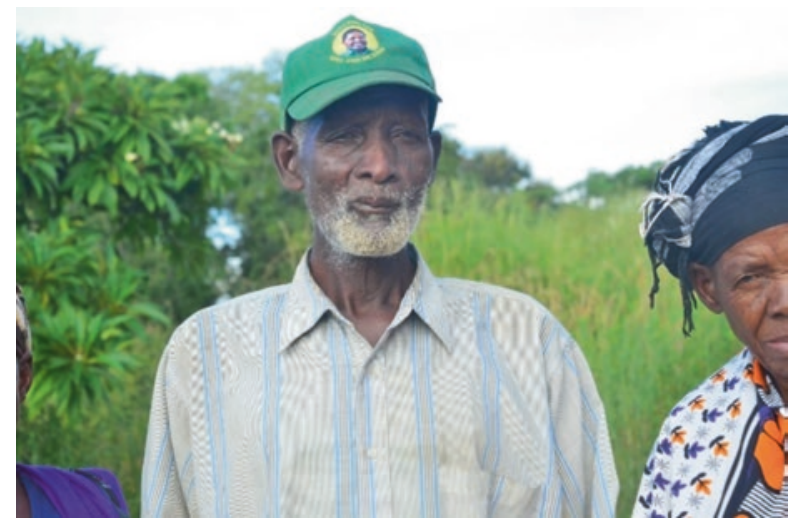

Fig. 2.4 Mr. Andera Shoko Kayanda, Secretary, Jumatuwa Farmers' Group shares their TL stories in Sabasabini Village, Ushetu District, Tanzania (Photo: Ndichu J) 


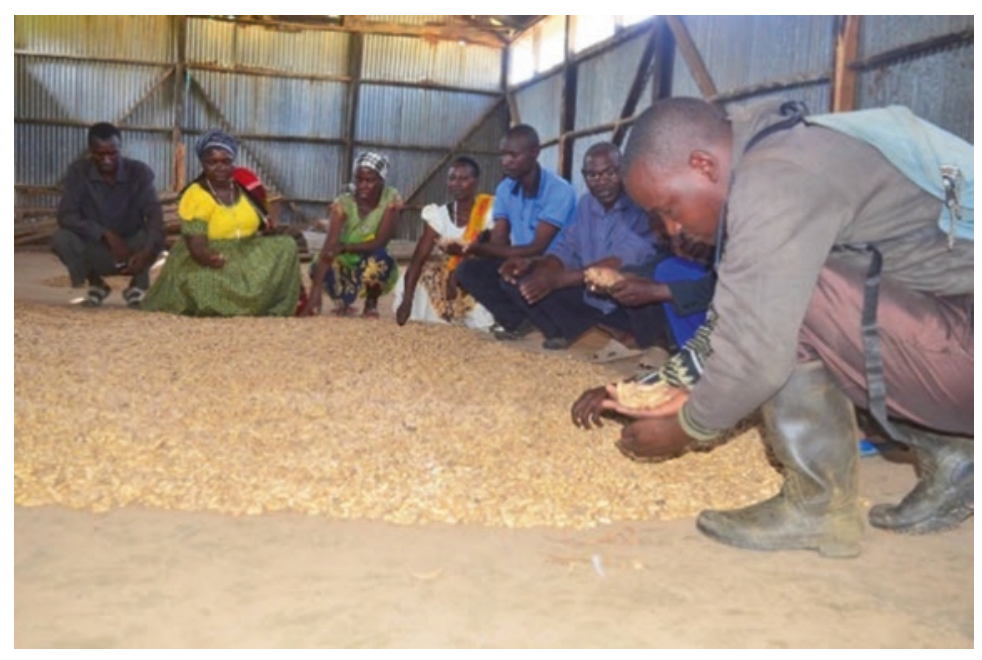

Fig. 2.5 Members of Jipemoyo Group showing their produce at their go-down in Kinanga, Kahama District, Tanzania (Photo: Ndichu J)

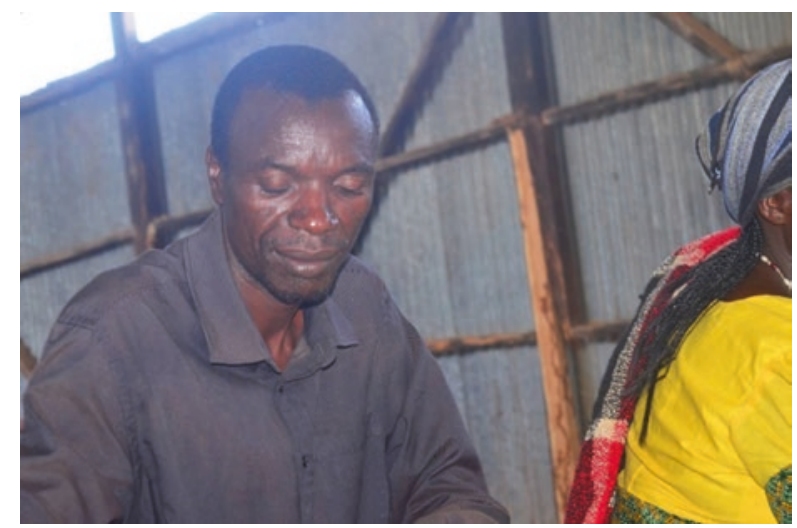

Fig. 2.6 Mr. Francis Paschal, a member of Jipemoyo Group, Kahama District, Tanzania (Photo: Ndichu J)

group secretary. Faraja says they got interested in farming groundnut after seeing how well other farmers in Mindola were doing after planting groundnut. "We got seeds from Naliendele and our expectations are to continue growing this crop. We hope to harvest the seeds and plough them back to expand our acreage."

Our farmer organisation has increased its production of groundnut from $50 \mathrm{~kg}$ to about $300 \mathrm{~kg}$ currently. "The value of the organisation has definitely risen. If you look at our equity and the infrastructure, putting everything together, the asset base has risen to over Tsh 70 million. I no longer rely on buying and selling, I am 
producing and selling. Then we have already expanded to other villages where we have other farms, for instance in Dodoma. There is still greater room for growth as long as we are in legume production," Mr. Chaula discloses to us.

The organisation's future looks bright; Chaula (Fig. 2.9) is currently writing a proposal to look for funds to put up a center pivot irrigation system infrastructure on his farms.

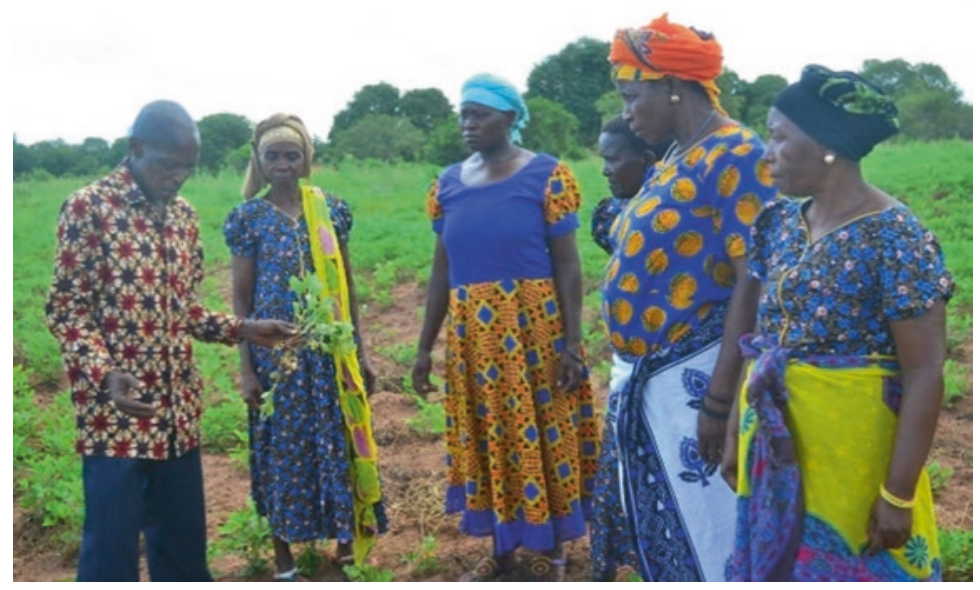

Fig. 2.7 Members of Upendo Women Group learning from researcher Charles Mkandawile at their farm in Mnanje, Masasi District, Tanzania (Photo: Ndichu J)

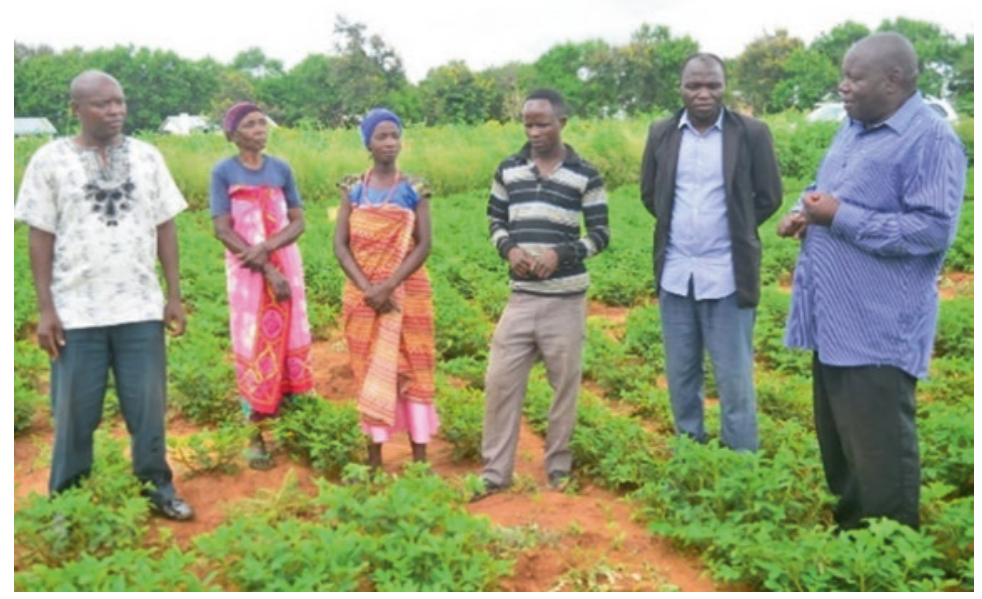

Fig. 2.8 Mr. Stephano Joseph (third right) with other members of Owe Faraja Group introducing visitors to their farm in Mindola village, Bahi District, with Mr. Anthony Sahali (first right) and Mr. Joel Mpayo (second right), Tanzania (Photo: Ndichu J) 


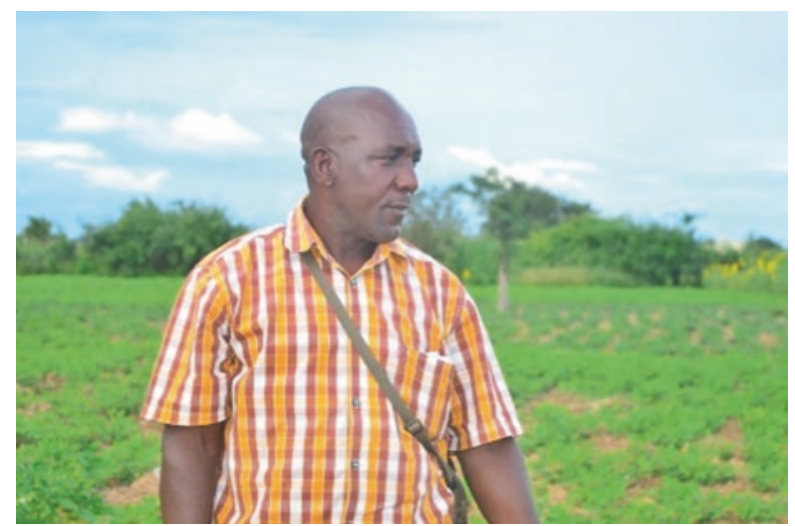

Fig. 2.9 Mr. Aithan Chaula showing DASPA farm in Dodoma, Tanzania (Photo: Ndichu J)

\subsubsection{Informed Decision-Making for Groundnut Production}

Apart from those farmers who farm groundnut for seeds, these farmers grow groundnut for subsistence use. They are basically grain framers. The 30-year-old Bushiri Rashidi Selemani, from Mpeta, Masasi District, whom we also met in March 2018, told us that he previously planted Pendo variety in his 1 acre piece of land and harvested 15 sacks of groundnut, despite planting late. "If I plant in good time and the rain is abundant, I will reap 20-25 bags for one acre."

Although he grows groundnut for food, Selemani said that with such harvests, he is selling the remainder to other farmers in his village. "I have been able to buy a bicycle, when I get a family of my own, I will take my kids to private school through this income, and still have money in my pocket. My life has surely changed," he stated, smiling.

Selemani (Fig. 2.10) would not let us go before passing an appeal to his government. "My call to the government is to take care of groundnut farmers the same way it has done for cashew nut farmers and get us planter machines, even if it's through loans so that we are able to grow in time. You know we can only harvest more if we plant in time."

\subsubsection{Improved Groundnut Varieties Planted at the Dispensary Farm to Teach the Nutritional Benefit to Communities}

In late March 2018, we went looking for people who have benefited through efforts of TL projects especially through groundnut in one way or another. We came across two institutions that have taken up farming of groundnut and are playing a significant role in knowledge creation and awareness. 


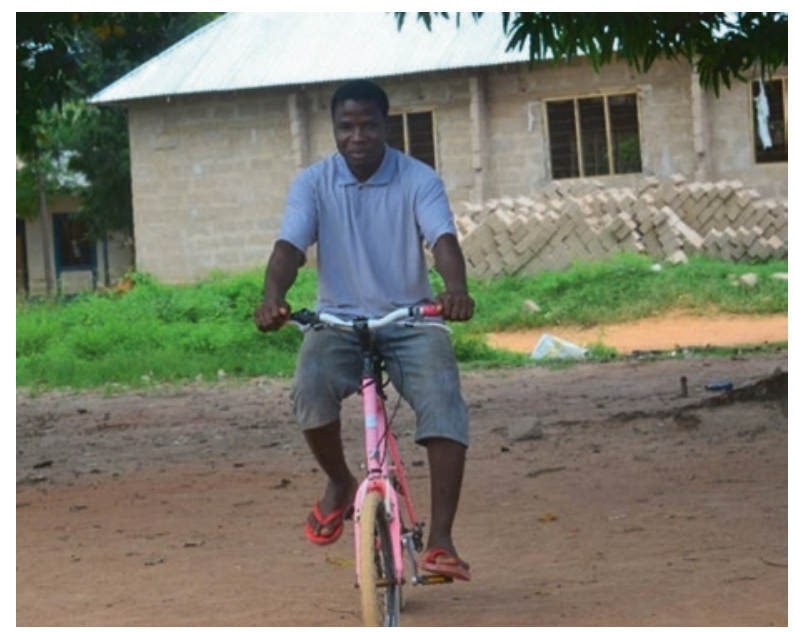

Fig. 2.10 Mr. Bushiri Rashidi Selemani shows his bicycle in Mpeta, Masasi District, Tanzania (Photo: Ndichu J)

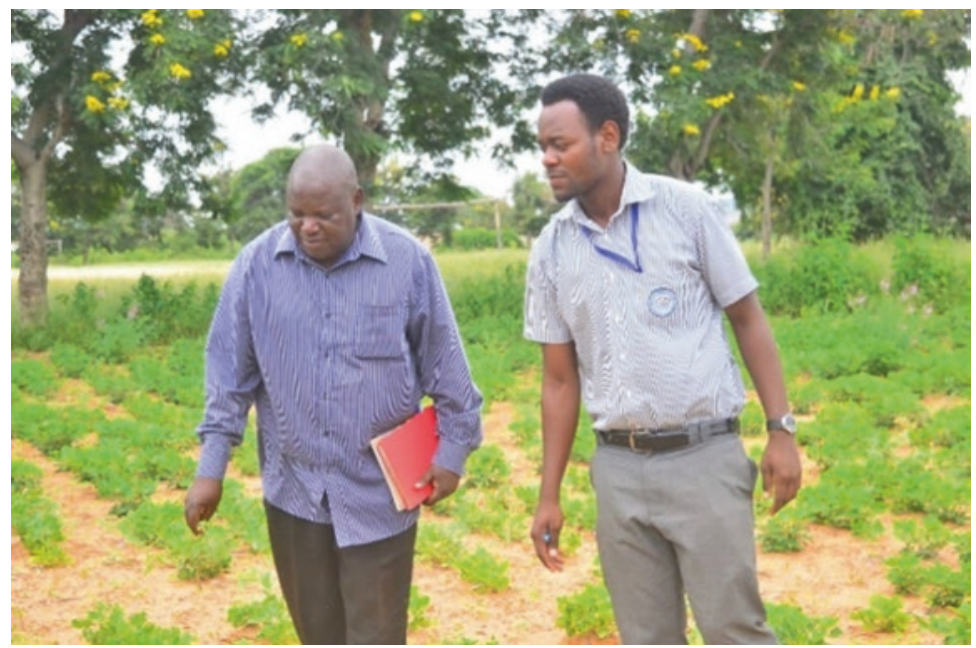

Fig. 2.11 Dr. Steve Julius (right) with Mr. Anthony Sahali at Ilindi Dispensary's farm in Ilindi, Bahi District (Photo: Ndichu J)

First is Ilindi Dispensary located in Ilindi, Bahi District (Figs. 2.11 and 2.12). Dr. Steve Julius, the doctor in charge, says they took up an initiative early 2018, through the help of researchers in Naliendele to plant groundnut at the dispensary farm and use that to teach patients about the benefits of taking groundnut as food. "The nutritional benefit of groundnut in the baby's body is the protein value. Groundnut in the porridge help with the growth of the child. Also, pregnant women need protein to avoid giving birth to underweight children." 


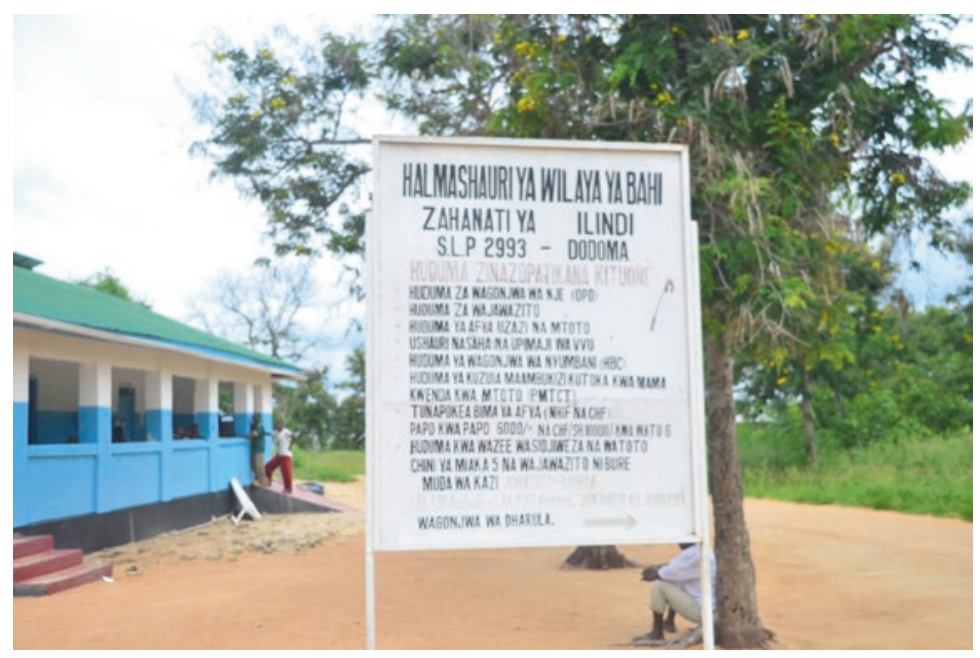

Fig. 2.12 Establishment of Ilindi Dispensary in Ilindi, Bahi District (Photo: Ndichu J)

Through these demos, Julius says that the community has taken up the lessons seriously and implemented the knowledge in their household farms. "After giving them training, there are about fifteen mothers who went ahead and planted the seeds at their home and they came to show us the results," he adds.

\subsubsection{Agricultural School Facilitating Community Access to Improved Varieties of Groundnut}

In Mnanje, Nanyumbu District, we met Mr. Ajili Mkero who is a teacher at Nanyumbu Primary School. He reported that the school has been growing groundnut since 2015 (Fig. 2.13). "Naliendele has been bringing these seeds to us every year and we can say that the collaboration has been good. I was fascinated by a group of women who were growing the new improved varieties, I started growing them myself, and I later introduced to my school."

One would be interested to know how the school goes about growing groundnut. Mr. Mkero says, "We teach the children how to plant groundnut in school and the groundnut become food for them. The children also get nutrients they deserve."

Other than getting food from the groundnut, the school has been able to benefit from selling the seeds. "When we sell groundnut as a school, we direct those funds to 'Elimu ya Kujitegemea' (self-reliance) department."

We can, therefore, say that relatively TL projects have been able to impact in a big way the lives of many people in Tanzania. In the local Swahili language, Tanzanians say, "Mgeni njoo mwenyeji apone," meaning let the guest come so that the host may benefit. That is exactly what the TL projects did when they were rolled out in Tanzania. 


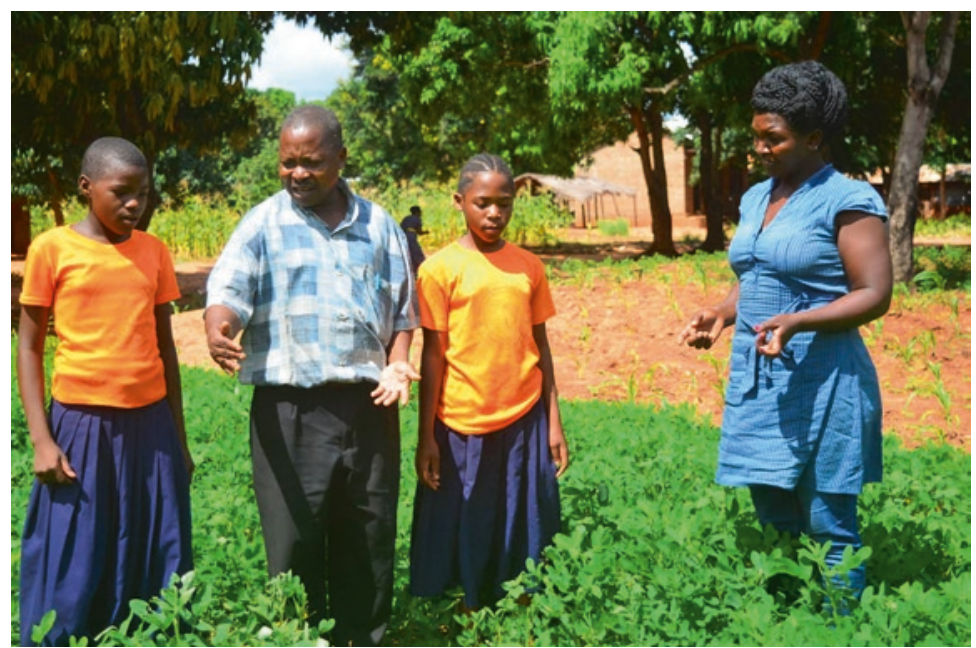

Fig. 2.13 Mr. Ajili Mkero between his students of Nanyumbu Primary School in Mnanje, Nanyumbu District at the school's farm, far right is Extension Officer, Ms. Leodina Ernest Mpagama (Photo: Ndichu J)

\subsection{Seed Companies and Agro-Dealers Got Interested in Groundnut Seed Business}

\subsubsection{Seed Companies Venture into Groundnut Business}

Prior to the TL projects in Tanzania, private seed companies were shy from selling groundnut seeds, either due to lack of market or lack of interest to do so. Things have since changed. Aithan Chaula, apart from being the District Agricultural Officer in Chamwino District, is also the manager of Dodoma Agricultural Seed Production Association (DASPA). "We ventured in the production of certified seeds because for over 10 years back, there were no such seeds here. We knew that many farmers were using their own recycled local seeds, so we introduced groundnut into the business, and by next year most of the agro-dealers will have more of our groundnut to sell," Mr. Chaula reported.

Mr. Chaula, through his association, is currently selling his products to over 10,000 farmers within and outside Dodoma. "We sell in packs of one and two kilograms directly to farmers but in the last two to three years, we have had organizations that are buying these seeds from us and distributing to farmers."

\subsubsection{Agro-Dealers Have Improved Their Business in Tunduru}

We met Ms. Zuwena Hamisi Chipangula (Fig. 2.14) at her company' shop, Tunduru Agro-Dealer in Tunduru District within the Southern Zone, in March 2018. The company began operations in 2002 and has been selling improved groundnut 


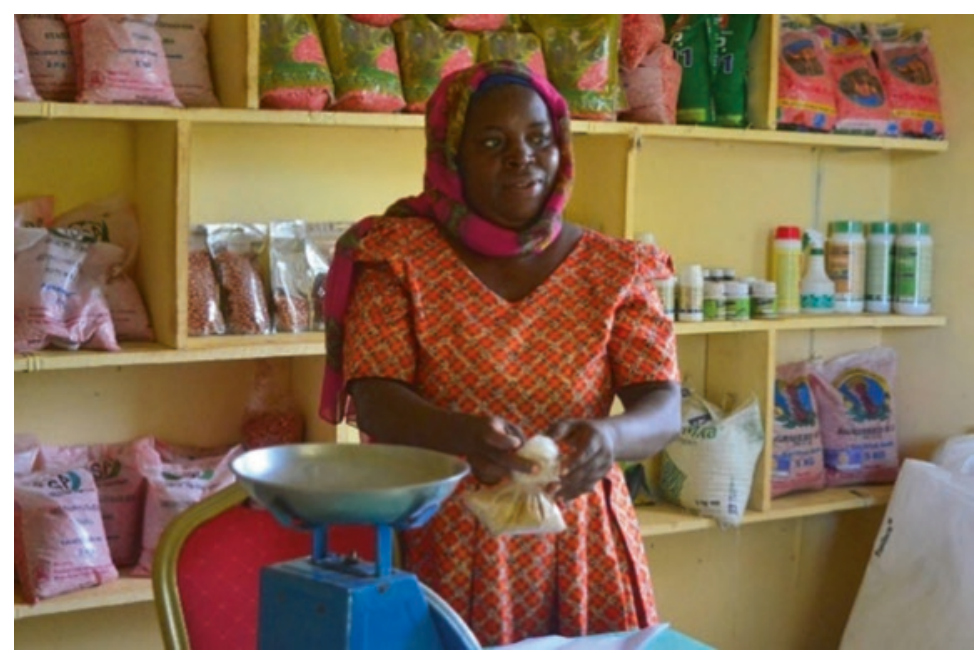

Fig. 2.14 Ms. Zuwena Hamisi Chipangula working at her shop; Tunduru Agro-Dealer in Tunduru District, Tanzania (Photo: Ndichu J)

varieties since 2013. "We deal with the sale and supply of agricultural products in southern Tanzania. The varieties of groundnut we are selling are Pendo, Mangaka, Naliendele, Mnanje, and Nachingwea," she says.

Chipangula has now familiarized herself with these new varieties and she helps us identify traits her customers like from these varieties. "Pendo is a variety that grows in a record 90 to 110 days. It has the capacity to give $1500 \mathrm{~kg}$ per hectare and can cope with diseases. Mangaka also grows within 90 to 110 days. It can give $1600 \mathrm{~kg}$ per hectare and provides three seeds for one pod. Naliendele also matures within 90 to 100 days, and it has the capacity to give $1000 \mathrm{~kg}$ per hectare. Mnanje, on the other hand, grows within four months and can produce up to $1000 \mathrm{~kg}$ per hectare. Lastly, Nachingwea grows in 110 days and it can produce $1000 \mathrm{~kg}$ per hectare."

Since she started selling the improved varieties, Chipangula says her business has grown by leaps and bounds. "We pack from half a kilo onwards, and so far, we have close to 1000 farmers who are our loyal customers. We sell four tons of seeds each year," she says.

Chipangula says she has been able to further her education through this business. "My business has grown because more people have gotten information about these new varieties and their characteristics and have embraced them." 


\subsection{Groundnut Processors and Traders Boosting Their Business and Making More Cash}

\subsubsection{Processors in Tanzania Now Processing Cash}

When an innovation comes, it does not just benefit its primary users; you may be surprised that others will take it up and use it more innovatively to make a living out of it. That was the case with Mr. John Julius Bakari (Fig. 2.15), who owns Temnar Company Limited, a company that makes vegetable oil. Temnar Ltd. is located in Masasi District.

He says when the new varieties of groundnut were introduced in Tanzania, he did not hesitate to engage with the researchers, to benefit from varieties with high oil content, through value addition. "Naliendele Institute has assisted us by providing groundnut that are rich in oil content, which is what we are interested in. When you look at the indigenous varieties, you can't compare with these improved ones. So, their technology has helped us a lot," Bakari reported.

He has mostly been selling his products to retailers as he says many wholesalers have not known about these new products, but he hopes with time, more people will embrace his oil products.

Bakari is a man who is full of gratitude. He says this innovation came to benefit people like him. He stated, "My Company has benefited a lot; I have seen its income rise since I now spend less on production while the output is high."
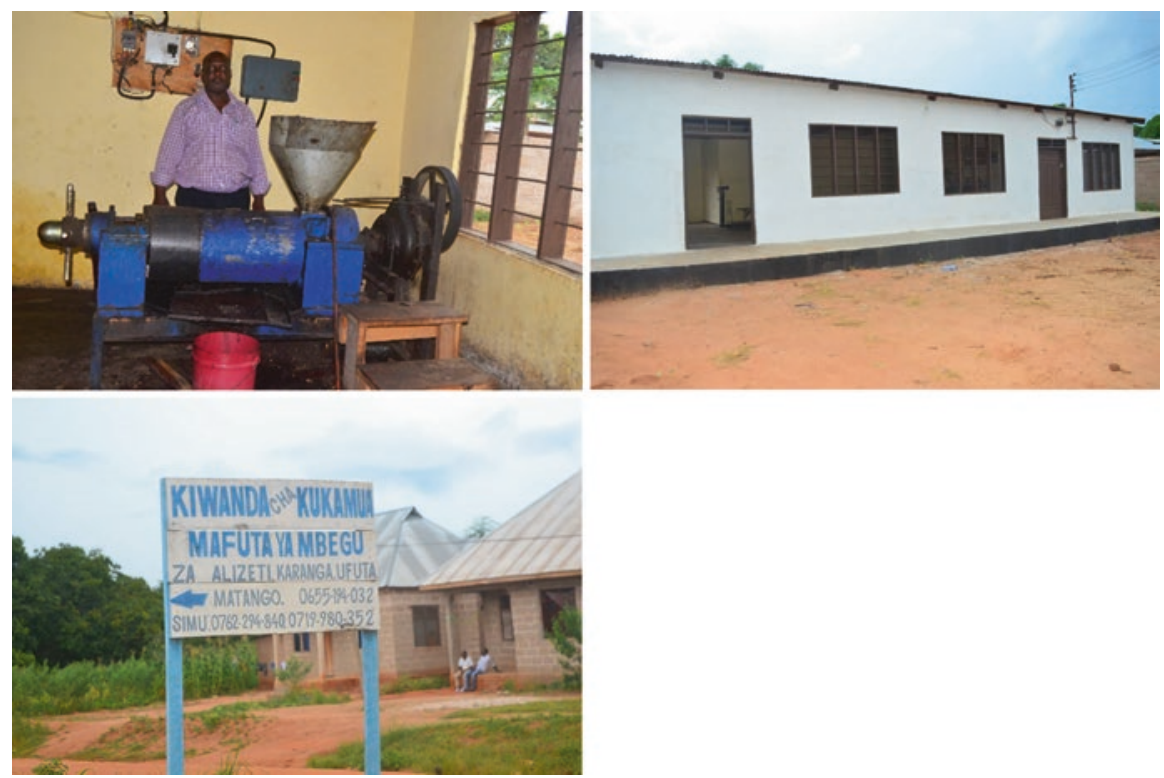

Fig. 2.15 Temnar company installation (Photo: Ndichu J) 


\subsubsection{New Business Opportunities Through Purchase and Sale of Groundnut in Kahama}

After talking to Mr. Samson Sumuni (Figs. 2.16-2.18) whom we saw earlier, as an agricultural extension officer, he mentioned that in Kahama Mjini, several businessmen have taken up the business of buying, shelling, and selling groundnut. We, therefore, sought to speak to one such businessman, and he took us to Mr. Simioni Edward, the owner and manager of Mungula Shelling Plant and depot at Mungula, in Kahama. This was in March 2018.

Simioni reported that in 2015 he saw an opportunity with the readily available groundnut from farmers. He now buys the produce from local farmers and exports the same to the neighboring Uganda and Rwanda. With a shelling machine and godown in his premises, Simioni can shell and store groundnut to sell in large quantities. "My machine has the ability to shell 200 sacks a day, while my warehouse can take about 60 tons when full.” His business, he says, cost him about Tsh 20,000,000 (about USD 8700) to set up.

On a good day, Simioni can buy groundnut from around 60 farmers each day. "For a day I can buy three or four tons and on a good day, I am able to buy up to twenty tons."

He has created employment through his business. "I have employed four workers on a permanent basis, but those who benefit directly are more. We have three more people who get up to Tsh. 20,000 (USD 9) daily by helping us to load and offload the goods."

Simioni said there are about three other plants like his in Mungula village alone! This speaks volumes about the impact of TL projects in Tanzania as a whole.

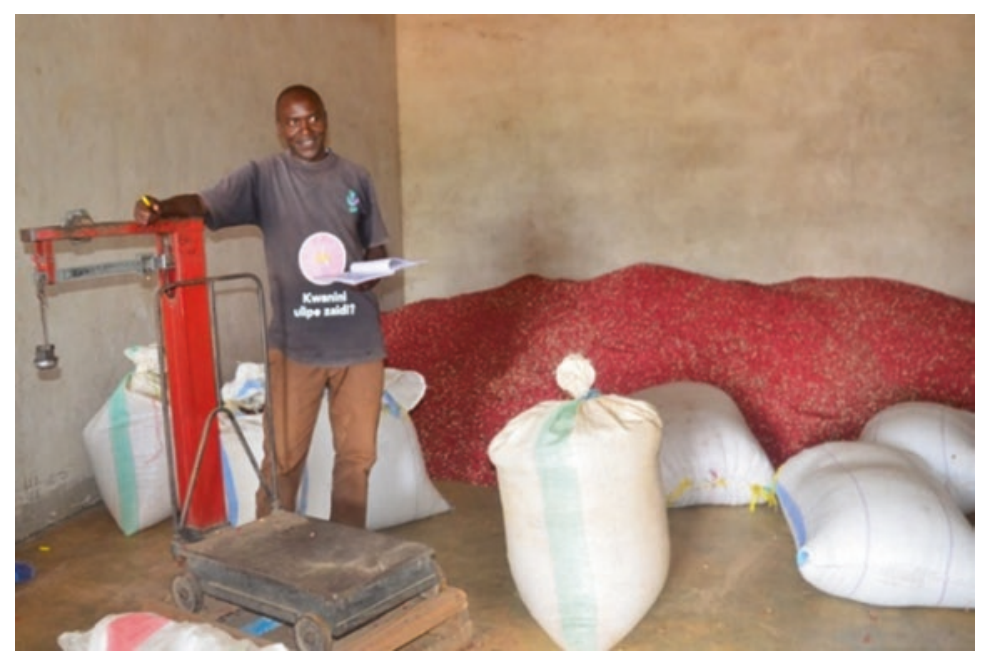

Fig. 2.16 Mr. Simioni Edward in his godown in Mungula, Kahama, Tanzania (Photo: Ndichu J) 


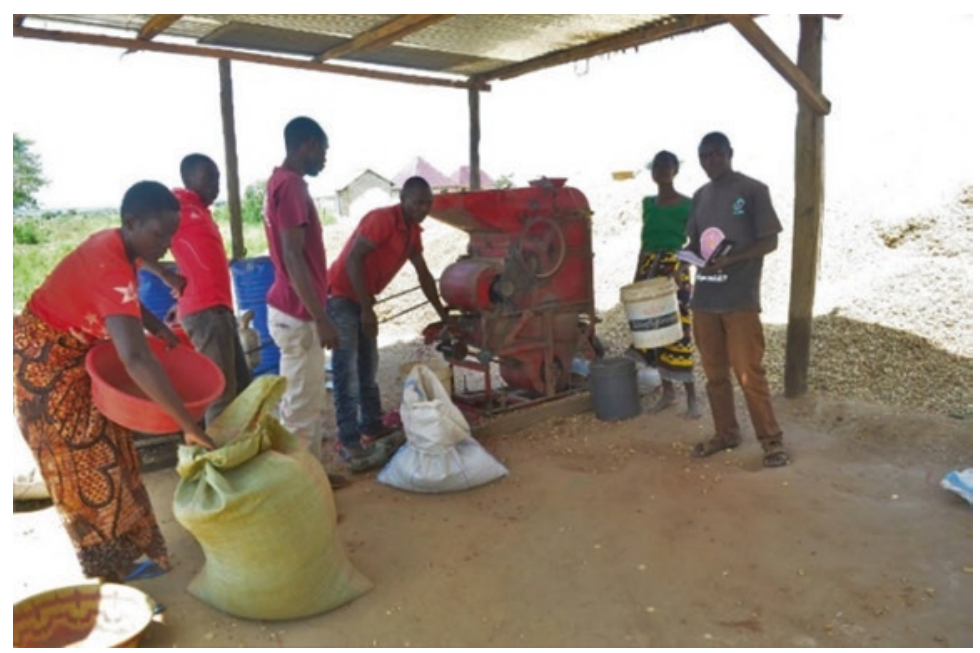

Fig. 2.17 Mr. Simioni Edward (extreme right) at his Mungula Shelling Plant in Mungula, Kahama, Tanzania (Photo: Ndichu J)

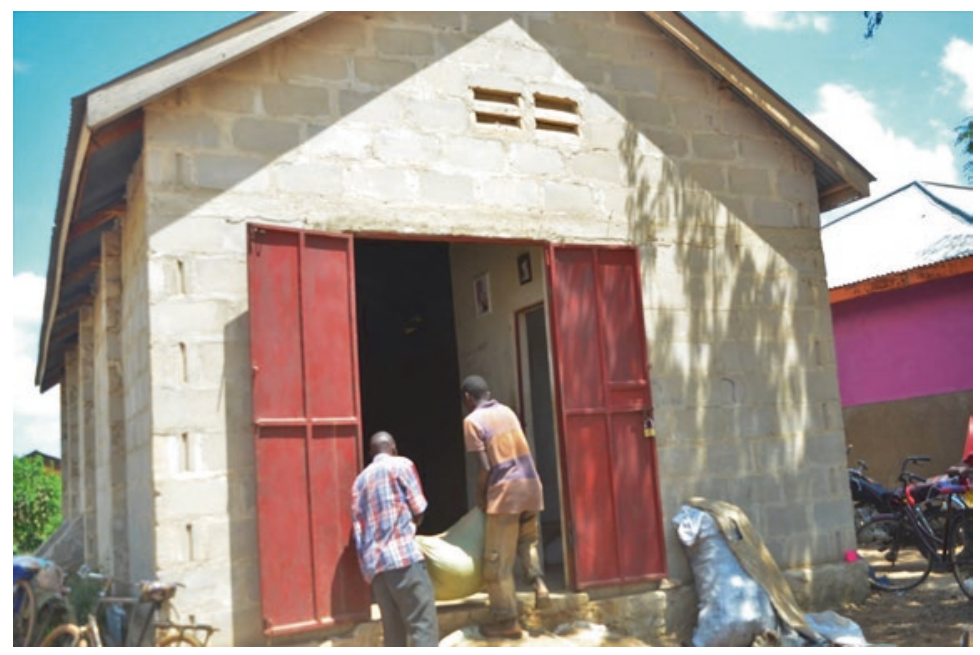

Fig. 2.18 Workers at Mungula Shelling Plant and depot at Mungula, in Kahama, Tanzania (Photo: Ndichu J)

In Ushetu, Manguzi (Fig. 2.19) reported that, due to the high productivity of groundnut, shelling machines can be heard all over the town. "Groundnut prices do not fluctuate like maize, giving the farmer a fairly stable income through the year," said Manguzi. 
Fig. 2.19 Mr. Aron Manguzi walking with us in Ushetu District, Tanzania (Photo: Ndichu J)
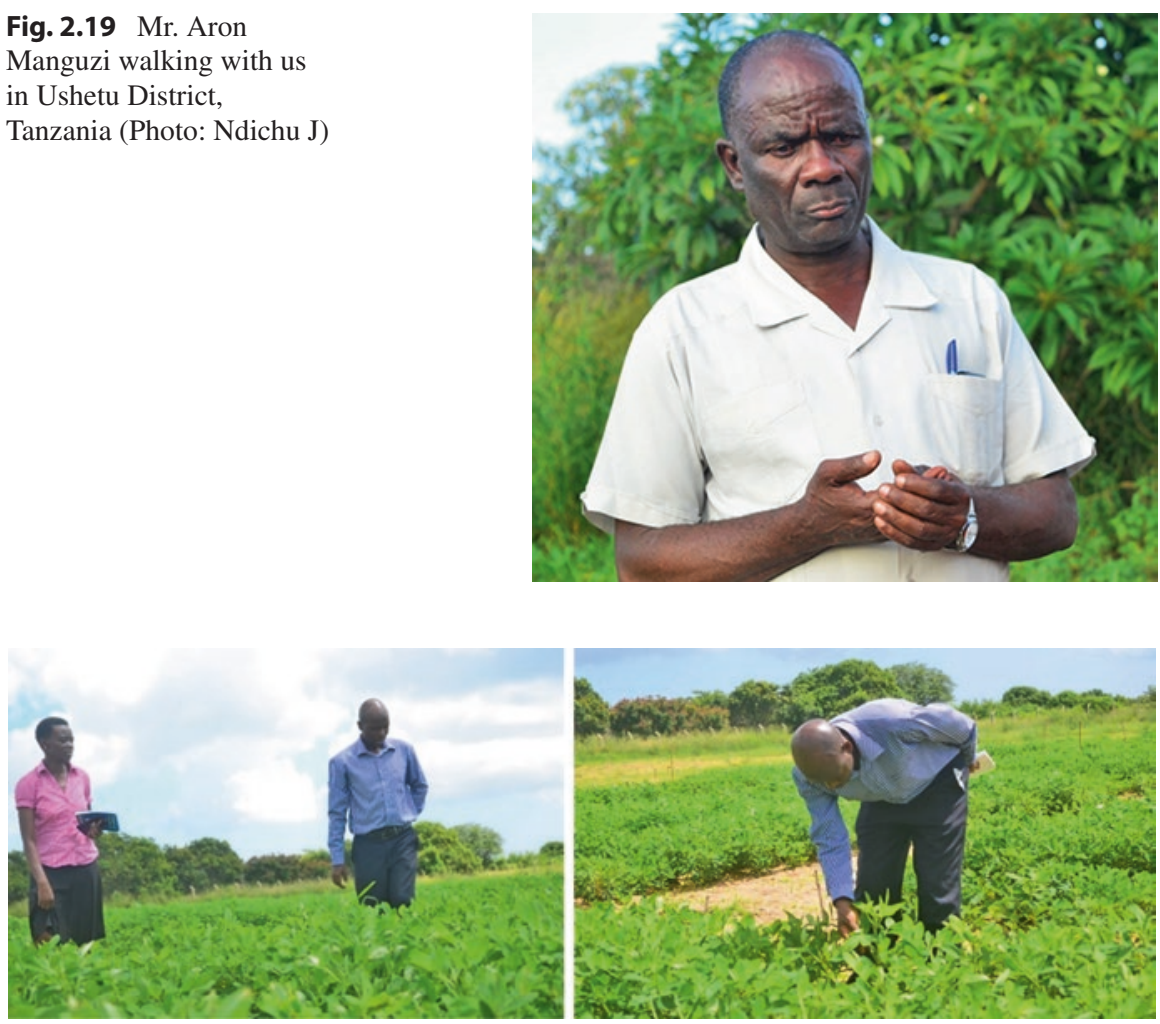

Fig. 2.20 Mr. Athanas Minja (right), with his colleague Happy Daudi, inspecting groundnut varieties at the Naliendele Institute's Crop Museum, Mtwara, Tanzania (Photo: Ndichu J)

\subsection{Researchers Share Their Views of Groundnut Breeding and Research Efficiencies Enhancement in Tanzania}

\subsubsection{The Breeder Who Is Glad to Have Been Alive When the TL Projects Set in Tanzania}

Mr. Athanas Joseph Minja (Fig. 2.20, right) is currently managing groundnut breeding under TL projects and working with farmer research groups to popularize groundnut varieties and crosses; developing groundnut varieties that are resistant to biotic and abiotic stresses like rosette disease and drought; and creating awareness on the issue of aflatoxin and the improved varieties.

Minja has been involved in the Tropical Legumes projects since 2007; we talked to him in March 2018.

We have been receiving the new germplasm from ICRISAT Malawi and ICRISAT India and we are using them to improve our released varieties in the crossing so that we can integrate those traits of drought tolerance and oil content. From ICRISAT Malawi we also received 
germplasm that are rust resistant, says Minja. He adds, We evaluate them, do a preliminary evaluation. From there, we do participatory variety selection (PVS) with the farmers to compare factors like yield and other traits. We then involve Tanzania Official Seed Certification Institute (TOSCI) and release after passing through all those stages.

The research institute has been able to release 17 varieties in total since 2007, 13 of which were released under TL projects. "Currently we have five set of trials; close to 1000 lines. The size of the nursery has been increasing, we are evaluating close to 1000 nurseries in Naliendele."

Recently we were able to release Naliendele 2016, Mtwaranut 2016 and Tazanut 2015. These varieties are high yielding, more than $1 \mathrm{t} / \mathrm{ha}$, and are preferred by the farmers and consumers in the market. This is because they take a short duration, therefore preferable in agro-ecological zones that have short rains. We also have those that fit heavy rain ecological zones like Southern Highlands. In such places, we advise farmers to use varieties that take medium duration like Mnanje 2009, or Naliendele 2016.

Minja says they have been working with different stakeholders, to multiply the improved new varieties, namely, Non-Governmental Organizations like World Vision and Agha Khan Foundation. In Mbeya district, which is found in the Southern Highlands, they have also engaged the Agricultural Seed Agency (ASA), a Public Seed Multiplier, and other private seed multiplication companies like Suba Agro, Agri-Seeds, and Meru Agro.

He says that the demand for these improved varieties has been growing high, due to popularization through the media. "We have engaged national television broadcasters like Tanzania Broadcasting Corporation (TBC), Azam TV, Star TV, and ITV. We also have engaged radio stations like TBC Radio, and newspapers like The Guardian and Daily News, to cover this information. Recently we got agricultural field officers from Katavi who said that they want to cover more than 20 acres of land with these new varieties since the ones they have been using have been suffering from rosette," a visibly cheerful Minja said.

Gender aspects have also been considered when releasing the varieties. "Women prefer the soft pod for ease shelling. They also prefer varieties with high oil content for relish making. Others would be colour; and you find that colour is sometimes co-related with things like iron nutrients. Some prefer red, others tan colour. Based on that information we can know during the crossing, what they prefer in the market. Traders prefer varieties that are big in size, while processors look at the oil content."

In terms of resources, Minja says TL projects have been very crucial. "For groundnut, we used to produce $300 \mathrm{kgs} / \mathrm{ha}$, but with the use of this new technology and with proper spacing and taking care of the field, we have been able to realize $1 \mathrm{t} / \mathrm{ha}$. Productivity has improved and now more farmers are planting groundnut especially the improved varieties. Farmers are now using proceeds they get from groundnut to manage the perianal crops, like cashew nuts." 


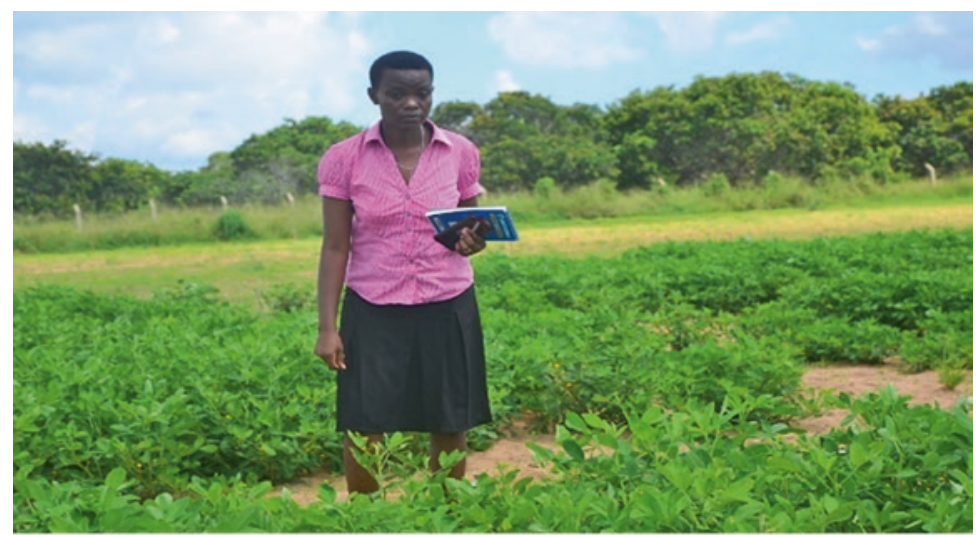

Happy Daudi inspecting her breeder varieties at

Naliendele Institute in Mtwara, March 2018

Fig. 2.21 Ms. Happy Daudi, a breeder who is also based in TARI-Naliendele in Mtwara, is undertaking her PhD under TL projects sponsorship, Tanzania (Photo: Ndichu J)

\title{
2.4.2 Happy, a Breeder at TARI-Naliendele, Is Now a Happier Breeder
}

\begin{abstract}
I am going to study groundnut breeding, especially on rust disease. As we know rust disease is a problem in coastal areas, where temperature and humidity are high, she said.

I currently have 120 breeding lines, 109 of which I got from ICRISAT Malawi, while others are the varieties that we released from Naliendele. I also have some old varieties that I collected from Shinyanga, Dodoma and here in the Southern Zone. My nursery is about 120 meters.
\end{abstract}

Daudi (Fig. 2.21) says the TL projects have been instrumental in her research. "I have benefited a lot as a student under TL through capacity building; I attended training on how to identify the disease and the impact they have through their breeders. We also received some germplasm from ICRISAT." This she says has strengthened their breeding program. "At the end, we will be more independent than dependent, because we have a lot of resources, like the germplasm."

\subsection{TL Projects' Investments in Research Infrastructure of the National Agricultural Research Systems}

\subsubsection{Irrigation Facilities Fully Installed at the Tanzania Agricultural Research Institute-Naliendele, Tanzania}

Daudi is thankful for the support that breeders at their research center got from the TL projects. "Other resources we have received are like this irrigation facility, this will help us because even for my study I will use irrigation.” (Fig. 2.22) 


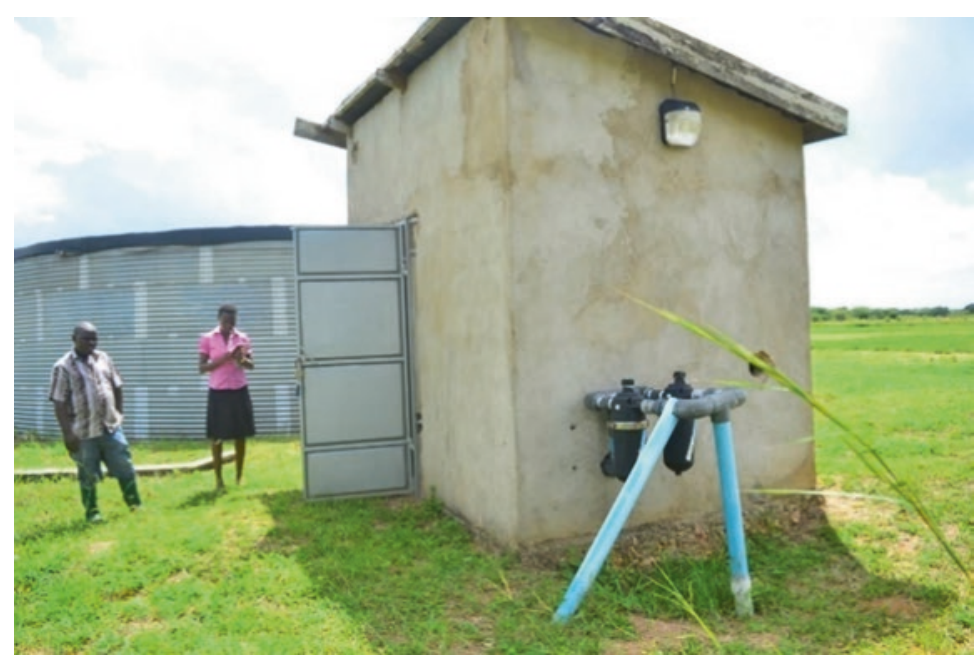

Fig. 2.22 TL III built irrigation facility at TARI-Naliendele, Mtwara, Tanzania (Photo: Ndichu J)

On the varieties she is working on in her study, Daudi had this to say, "For my $P h D$, I selected a few varieties, I have around 6 improved varieties, the local ones, and new lines that have not been released. In the end, I will come up with my variety which is resistant to diseases. I have not been able to release any variety, because I am in my second year of study, so I am still going to the trials."

From her own experience, she has used varieties like Pendo which she says is an improved variety although there are new developments. "Farmers prefer it a lot, but it has its own challenges. It is susceptible to all foliar diseases like rosette, rust, and leaf spot, which is the main challenge. But the new ones are resistant to diseases, are high yielding, and have high oil content." She adds that, more awareness on the newer varieties needs to be done so that farmers can embrace and reap from them.

\subsubsection{The TL Projects Have Catalyzed Our Work of Research, at TARI-Naliendele, Mtwara}

Dr. Omari Mponda (Fig. 2.23), the acting Southern zone regional director, TL projects principal collaborator in Tanzania, and a Seed System Scientist, is grateful that The TL projects happened in his country. We met him in his office in March 2018. "Tropical Legumes projects have helped because most of the scientists had already been trained in farming systems research approaches. The training focused on the need to involve the client in the technology development. Therefore, we have been very successful in disseminating our groundnut varieties through those participatory approaches. We can now say that in Africa, Tanzania is currently second after Nigeria which is producing 3 million metric tons while in Tanzania, we are producing about 2 million metric tons. So, the graph on the production of groundnut has 


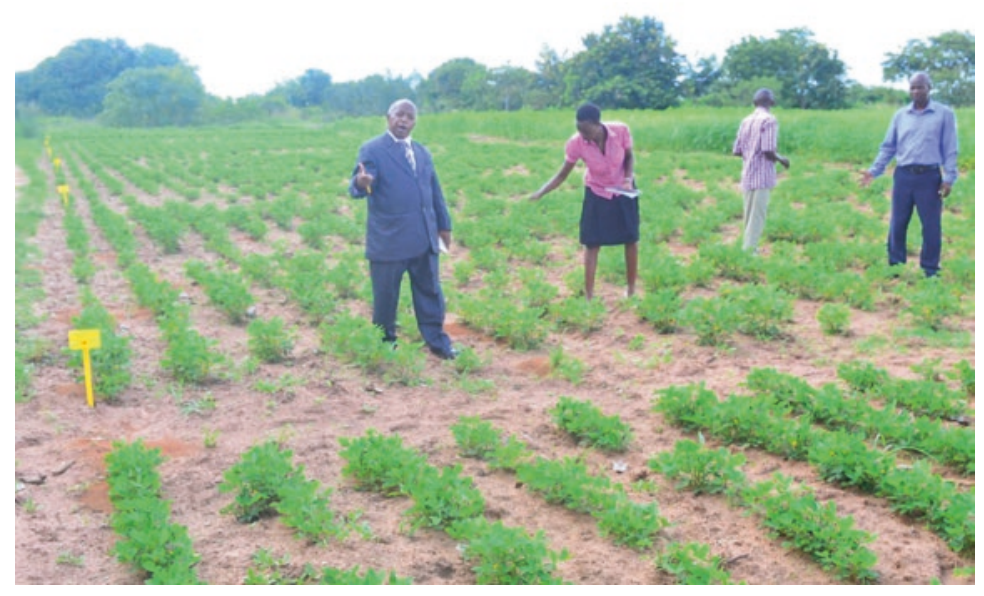

Fig. 2.23 Dr. Mponda (extreme left) takes us round the Naliendele Institute's Crop Museum, Tanzania (Photo: Ndichu J)

been on the increase and growing very fast from 2007 when we started till now. I think we have done a lot of things," says an upbeat Mponda.

He reported, "Within groundnut, we have several objectives, but the main ones are new varieties that are resistant to biotic and abiotic stresses, including some agronomic recommendations that will increase productivity at the farm level."

Dr. Mponda adds, "We have a seed roadmap, to make sure that over the 4 years of support from Tropical Legumes, we produce about 8000 metric tons of groundnut certified seeds in Tanzania. Therefore, we have been trying to reach the target over the years, and each year we produce something depending on how many farmers we have reached. But I think we have done very well in groundnut seed production in Tanzania."

TL projects impact cannot be simplified better than this: "Initially the average productivity for groundnut was only 300 kilogram per hectare, but now it's almost $1 \mathrm{t}$ /ha because of the adoption of the new improved varieties which have improved productivity,” Mponda breaks down.

Dr. Mponda compares what his research institute was able to achieve over the years with what they have achieved in about 10 years of TL projects in Tanzania. "From our research, we have at least 13 varieties of groundnut that we have released since 1978 with previous programs. Now with Tropical Legumes projects in general that started in 2007, I think we have been able to release 11 varieties because the first variety was released in 2009, then 3 varieties were released in 2015, and now this year we have released 3 varieties adding up to the 11 existing varieties. These varieties command high yielding ability, they are resistant to rosette and some of them are drought tolerant. Also, we develop varieties depending on their demand. The Tanzania market requires a conventional market, so we develop varieties that are large-sized. We are also developing varieties that are high oil content, so we can have some groundnut vegetable oil from it." 
We ask about the varieties that have been released and how they are faring in the market. "Of the most popular varieties, one is Pendo that was released before TL III and this is our own variety which I think the adoption rate is something about $60 \%$. With Tropical Legumes support, we have another variety called Mnanje that is also commanding high popularity. The other one is Mangaka and this is one of the varieties that was developed from ICRISAT, we tested it in our elite variety trial and eventually, we released it. It is also high yielding and mostly preferred in the market. The Tanzania market requires varieties that are easy to shell. Mangaka is good for them because it is easy to crack, so they don't use a lot of force, which is why it is highly preferred. Another variety that is common in Tanzania is Naliendele 2009. This one is a drought tolerant crop, early maturing and here in southern Tanzania it is largely grown in Masasi which is a drought-prone area. They receive very little rain, and I think it is also good for people in the arid areas like Dodoma and Singida. This one will be highly accepted by those farmers."

Perhaps, a point is easily driven home when it's heard from the key stakeholders themselves. Dr. Mponda narrates a story of a farmer who was pleasantly surprised at how much she could reap from groundnut. "I had a call from one of the farmers, Angelina in Singida. She told me that the Naliendele 2009 variety I gave her has done wonders. It is very small in size but when you uproot it, it has so many groundnut. She was very happy!"

The Research Institute has done pretty well in popularizing the varieties with the support of TL, according to Dr. Mponda. "At Naliendele, we have the Zonal Information Extension Liaison Unit. This one links to research and extension as it is the one responsible for organizing farmer field days, agricultural shows, producing leaflets and responsible for coming up with press releases to link with the media. Every year, we host media personnel either from Tanzania Broadcasting Corporation $(T B C)$ or ITV whereby we send them to our project sites, they talk to farmers and get to see what the farmers are getting from the TL projects, and the challenges they may be facing. So, we broadcast our activities through radios and televisions. We could have 10 to 20 programs in a year."

The greatest challenge as Dr. Mponda puts, however, is the lack of enough market for what the farmers are now able to produce. "In Masasi, some farmers in one year failed to sell their groundnut because there were no traders to buy the products, but if the market is well known, they will be able to sell. We therefore need improvement in that area. Otherwise, we have done a lot in convincing farmers to adopt the improved varieties, and productivity increased immensely." He adds, "What is actually hindering further increase is lack of a marketing board for groundnut. I remember in 1970s and 1980s, we had general agricultural products for exports marketing body, and it was helping farmers in marketing their produce outside the country; there was always a market for all produce and the farmer knew where to sell. After that era, people have been producing but with nowhere to sell. We now need a groundnut' marketing board so that farmers can get encouraged to produce more. Currently the available buyers collude and buy at very poor prices. My appeal to the government of Tanzania is to assist these farmers by marketing their products." 


\subsection{Sensitivity Towards Gender Equality and Equity}

\subsubsection{TL Projects Attribute Success to Among Other Things, Sensitivity Towards Gender-Related Issues}

In a project of this magnitude, one cannot forget to consider the question of gender if the project is to release success. Professor Joseph Hella is a gender and social scientist at Sokoine University of Agriculture and has been working on the TL projects since 2015. He narrates his experience working with farmers to promote the adoption of improved groundnut varieties in Tanzania.

When you look at groundnut, it is a woman's job in that it's labour intensive. It requires more work. Since it's a highly marketable product, the men come in at marketing stage. So basically, it's a woman's crop in the garden and the men take over after harvesting.

\subsubsection{Professor Joseph Hella in Morogoro, Tanzania, in March 2018}

The new improved legumes uptake has been impressive among women. The women have seen the benefits especially now when the rains have been short but there is a lot of potential in bridging the gender yield gap, says Prof. Hella.

On the question of technology use among men and women, Hella (Fig. 2.24) had this to say, "The use of technology is really low. We collected this data from 900

Fig. 2.24 Professor Hella with a groundnut trader in Morogoro, Tanzania (Photo: Ndichu J)

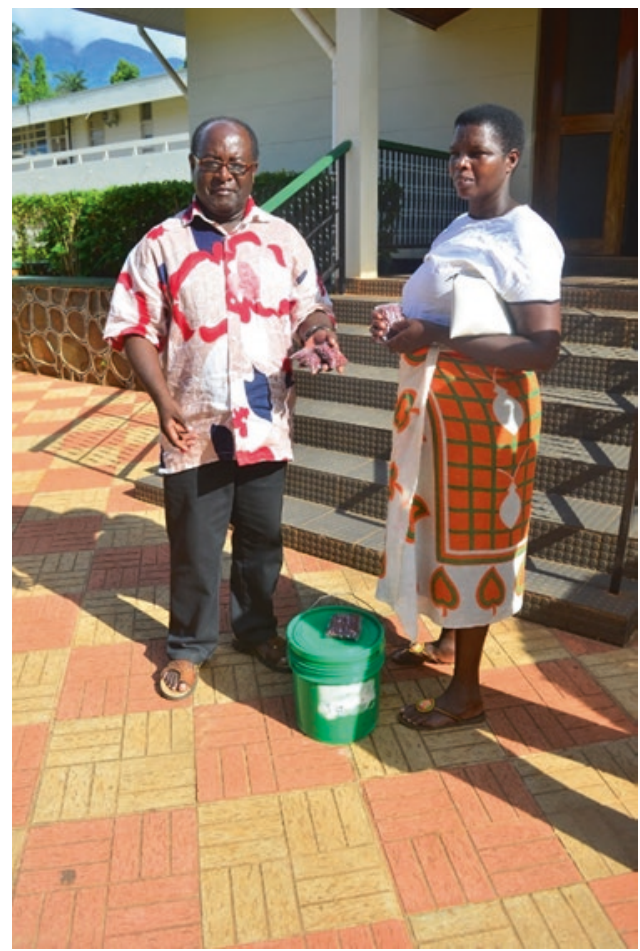


farmers and their productivity is really low if you compare their potential yield and actual yield. In terms of percentage, the yield from the women is really high compared to the men while the marketing percentage from the men is high compared to the women."

There has been the use of innovation too. "They implemented methods to ease the labor input directed towards groundnut growing. The use of these good seeds has improved their yield and they tend to grow fast so it's something positive. The drawback is the number of rains that come. If the rains are heavy, then the groundnut sometimes may not withstand. Innovations in terms of marketing, TL has installed a lot of knowledge which has seen farmers getting involved in variety choosing. Life changing decisions on farming groundnut has seen farmers meet their basic needs. The farmers have also developed group marketing seeing those targeting specific markets bringing in a value chain," he reported.

Professor Hella has witnessed first-hand, the impact that adoption of the new varieties has had among the farmers. "The lives of farmers have changed since they are getting good harvests." There has not been without challenges though. "The problem they have is getting seeds. This can be corrected through knowledge sharing and communication. Gender wise we are pegged at 20 percent in reaching out to farmers who are using improved seeds. We don't have good machines logged towards groundnut. With groundnut, we have a lot of variety but what we lack is the multiplication of seeds. Few farmers know about these seeds."

\subsection{TL Projects Extended Research Capacity Building Beyond Focal Research Centers Across Tanzania}

Ms. Felista Joseph Mpore is an Agricultural Research Officer at Tanzania Agricultural Research Institute-Makutupora (TARI- Makutupora) in Dodoma. The research institute is in the Central Zone and has been working hand in hand with TARINaliendele in groundnut seed multiplication under TL projects. We talked to her in the month of March 2018.

Mpore (Fig. 2.25) says that there has been a lot of changes that the TL projects have brought to her research institute. "There is an introduction of new varieties within the centre which were not present at the beginning; like Pendo, Mnanje, and mangaka varieties. This has helped our centre to provide new variety to farmers in nearby villages," she adds. "Due to the nature of the environment of the Central zone, groundnut is the second cash crop, making the crop important to farmers here. The availability of the groundnut is hence important for the Central zone."

Mpore gives us visible differences farmers in the Central zone have identified between the improved and the old varieties. "We can compare in production where the local varieties are not drought resistant, but the new varieties are. They can withstand the dry spell from February and when the rains come they start flowering and the farmer starts harvesting crops as usual but farmers who plant the old varieties end up with zero harvest." 

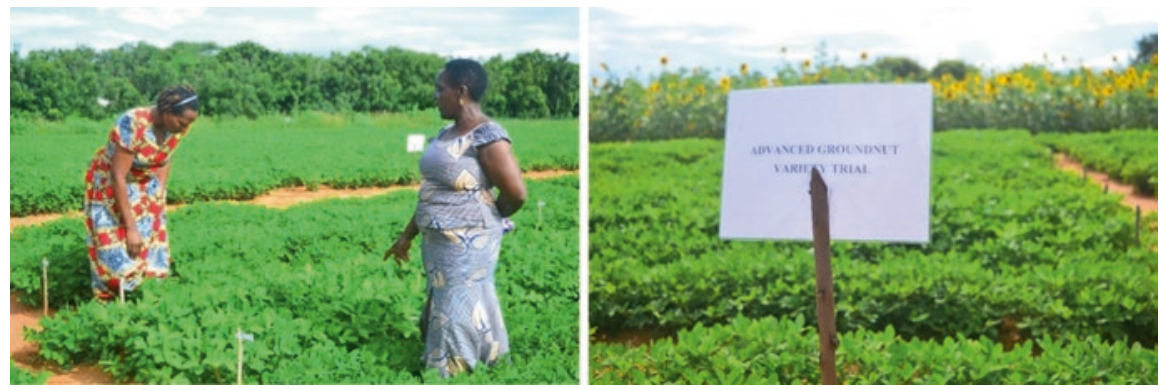

Fig. 2.25 Ms. Felista Mpore (Left) with Ms. Nuru James Mgale; both Agricultural Research Officers at TARI-Makutupora's farm, Tanzania (Photo: Ndichu J)

Mpore is satisfied with the uptake of the improved groundnut varieties within the Central zone. "I can say it is very high that even last year the seeds we had were not enough. If you move across the whole of Dodoma for example, the need for the new variety seeds is very high but the production is still low. Probably it's because there are no farmers that are involved directly in the production of seeds. The seeds are still in the Research Centre," she says.

She is calling upon the government of Tanzania to chip in and assist the institute by availing more funds to enhance seed production. "We know that the production of seeds is key for crop production. If you fail in producing quality seeds you fail to get the quality plant so if the government can support the seed production, I think we are going to fill the gap of seeds we have in the Dodoma region."

\subsection{Digitization of Data Collection Practices Becomes the Common Practice Within the Research Programs}

Mr. Charles James Mkandawile is a Principal Research Assistant (Fig. 2.26), based in Agricultural Research Institute-Naliendele (ARI-Naliendele). He is currently working as a research technician under groundnut program, and his main activities include trial management. His daily duties involve preparing trials, but sometimes he is engaged in planning those trials, that is, packing seeds and planting. He also does all the data collection, management, and analysis. He has been working on the TL projects since 2007.

Mkandawile is full of gratitude to the TL projects. "I think I should be thankful to the TL I, II, III projects, during the whole time I have received a number of shortterm courses. I attended a course in India, I have also attended several courses in Malawi on disease causes, and I have also attended a course on data management and analysis in Ethiopia and Malawi" he narrates.

He says that his life as a research technician has significantly changed since the TL projects set in Naliendele. "Before the start of these projects, we were using conventional methods; using items like calculators, collecting data using plain papers, but TL for instance, has empowered us and introduced items like a tablet. We now have specialized tools to undertake our work effectively. I can say we have 


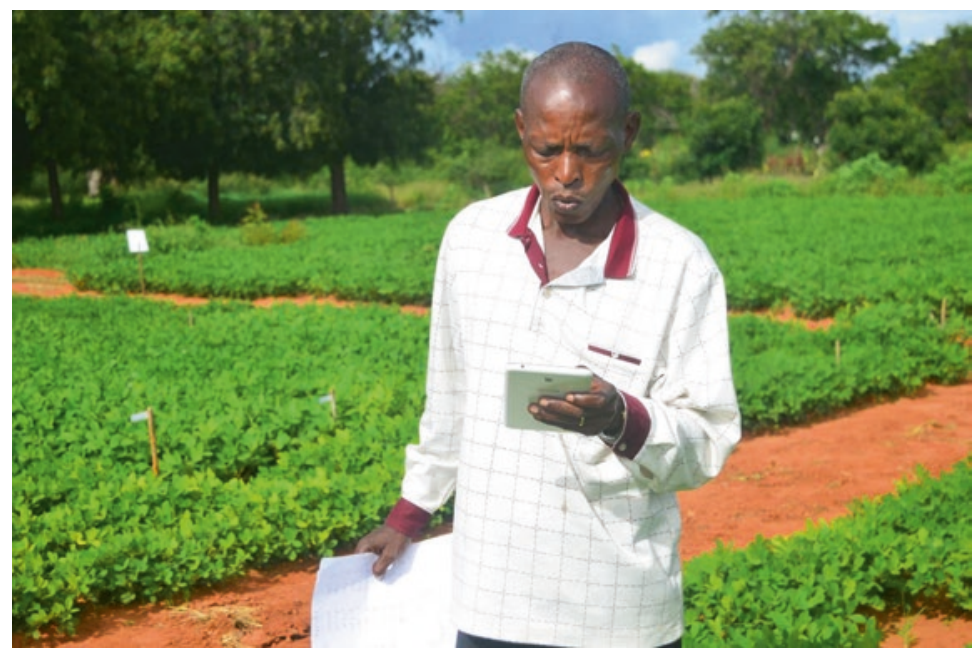

Fig. 2.26 Mr. Charles Mkandawile, a research technician, using a mobile application to collecting data on trial at Tanzania Agricultural Research Institute, Makutupora, in Dodoma, Tanzania (Photo: Ndichu J)

benefited immensely from these projects. Through the trainings and use of improved technologies, I am now able to work more in less time, unlike before."

Mkandawile says that farmer participation has been of utmost importance. "I have worked with farmers on on-farm trials, where apart from variety selection; we also use this opportunity to train them on other management practices for improved groundnut varieties. We also do demonstration plots from which we conduct field days, and Nane Nane shows (Agricultural Exhibition) so there is a lot of interaction between us and the farmers."

\subsection{TL Projects Make Work Easier for Agricultural Extension Officers in Tanzania}

Extension officers across different regions in Tanzania who got involved in TL projects too have success stories to tell. We talked to Ms. Leodina Ernest Mpagama from Mnanje, Nanyumbu District, Mr. Loti Philipo Molleli from Mpeta (Fig. 2.27), Masasi District, both in the Southern Zone, Mr. Joel N. Mpayo from Mindola, Mr. Anthony Sahali from Ilindi, both of which are found in Bahi District within the Central Zone, and Mr. Samson Sumuni from Kahama Mjini, in the Lake Zone. Although from different regions across Tanzania, these five share a common story of how farmers have now been able to improve their livelihoods through embracing improved groundnut varieties.

The extension officers have all gone through training which they transfer to the farmers. For instance, Molleli reported, "Some of the teaching I remember I went 


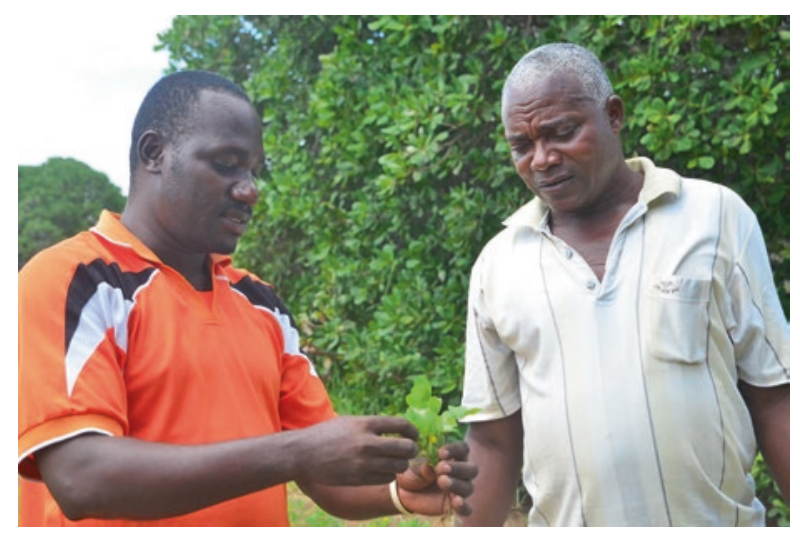

Fig. 2.27 Mr. Loti Philipo Molleli (Left in both photos) explaining disease diagnosis to Mr. Nyirenda, a farmer in Maugura Village in Masasi District, Tanzania (Photo: Ndichu J)

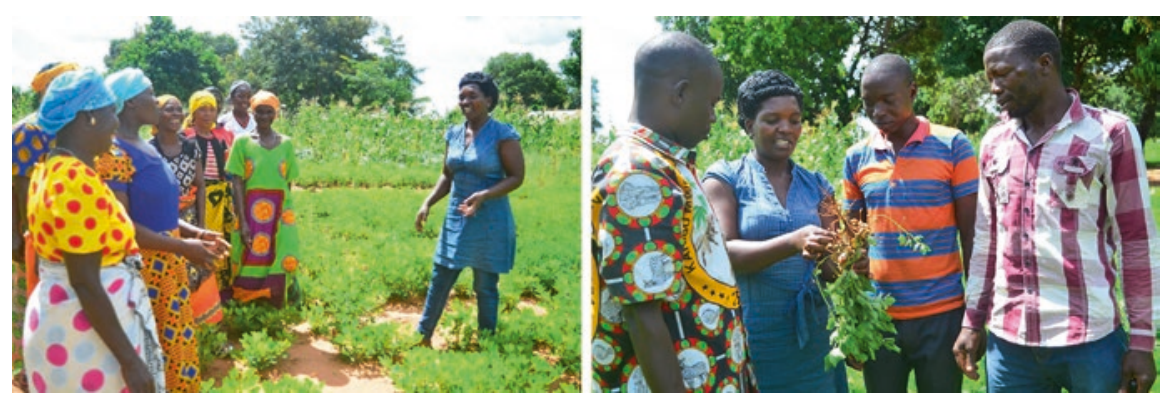

Fig. 2.28 Ms. Leodina Ernest Mpagama (in dark blue shirt) teaching women and youth farmer groups best practices in groundnut farming at Mnanje, Nanyumbu District, Tanzania (Photo: Ndichu J)

through from Naliendele is how to help farmers use the improved seeds and planting them using the right spacing."

In the course of their work, these extension officers meet and interact with many farmers within and without groups. "I train many groups on how to plant the new improved groundnut varieties, but I deal with more individual farmers than the groups. In Mnanje alone, for instance, I have about 2700 farmers. I train them five days a week especially during the planting season," Leodina said (Fig. 2.28). Loti, on the other hand, is working with five groups of an average of 20 farmers each, and over 100 other individual farmers.

In Ilindi, Sahali (Fig. 2.29) says he was able to target special groups, which are now able to meet their needs through the production of groundnut. "We have a women's group that takes care of orphan children. These women needed a source of income to raise the children, and groundnut came in handy. There is also the youth who are susceptible to moral decay due to lack of funds. Many ladies especially will tend to go to the city and engage in prostitution. To keep them in the village, one 


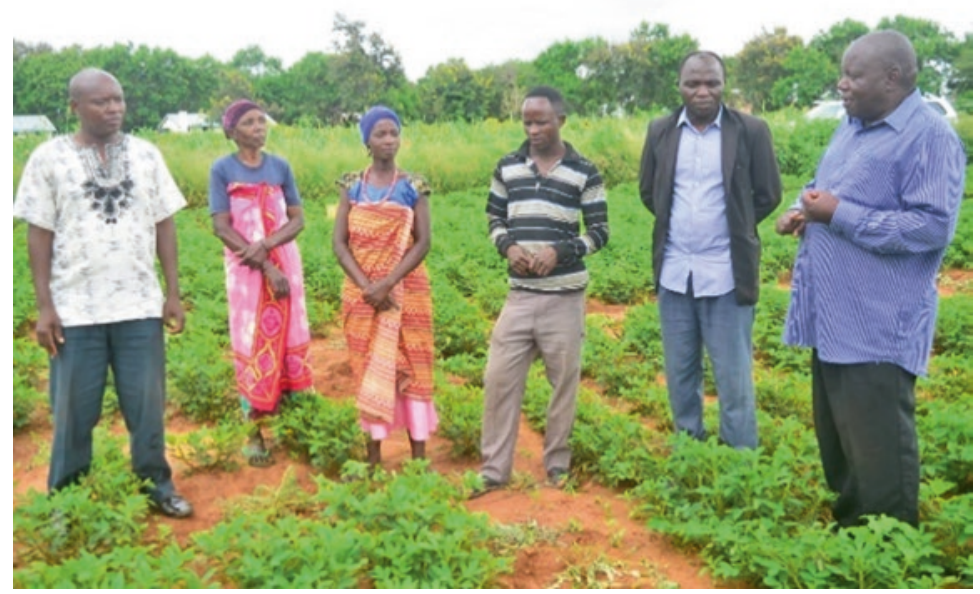

Fig. 2.29 Mr. Anthony Sahali (extreme right) with Owe Faraja Group Members in Ilindi, Bahi District, Tanzania (Photo: Ndichu J)

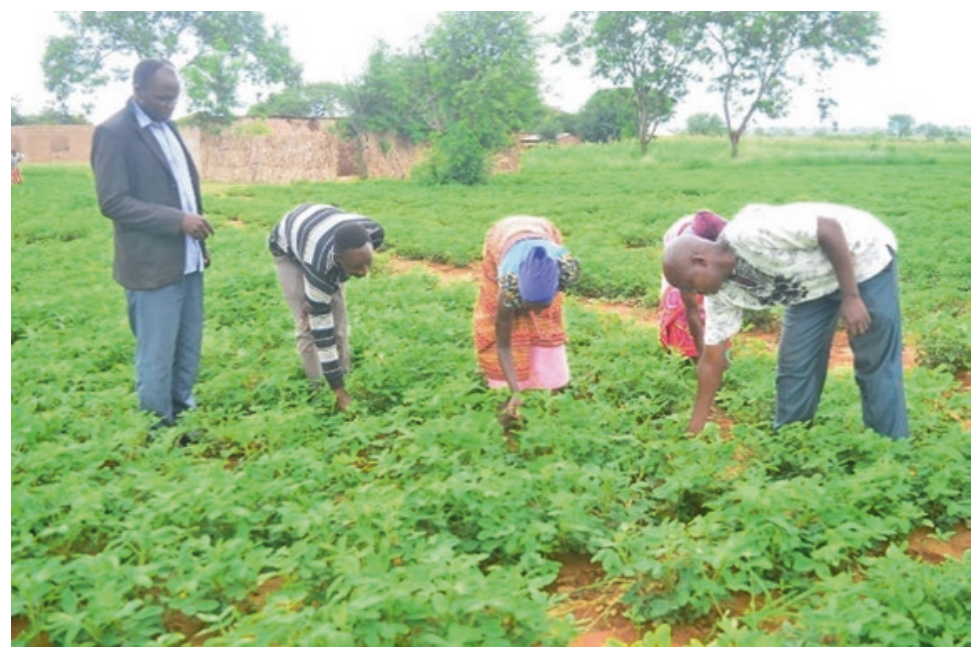

Fig. 2.30 Mr. Joel N. Mpayo from Mindola (extreme left) talking to Owe Faraja Group members in Bahi District, Tanzania (Photo: Ndichu J)

need to give them something to do, and what a better way than through groundnut farming" he says. The role of these extension officers is huge in the passing of knowledge to farmers within the villages and remote communities.

In Mindola, Mpayo (Fig. 2.30) said of a unique approach they have employed. "Agriculture fraternity within Mindola decided to focus on educating school pupils about these new groundnut varieties because as they grow old, they will have been 
Fig. 2.31 Mr. Samson Sumuni going through records in his office in Kahama District, Tanzania (Photo: Ndichu J)

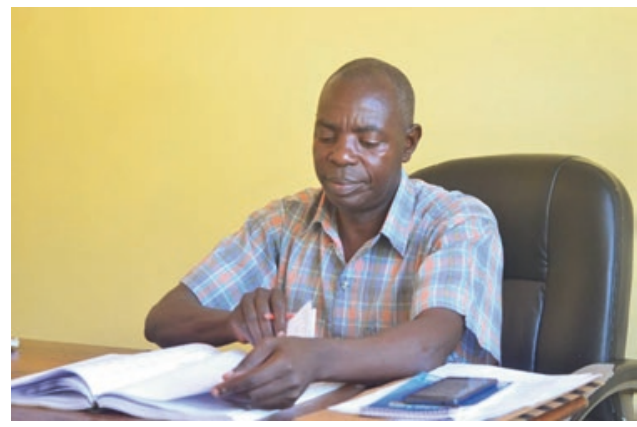

inculcated with the practice of this kind of farming. They will also be able to pass this knowledge to their parents, and it will be faster to spread this knowledge," says Mpayo.

In Kahama, Sumuni (Fig. 2.31) told of the success story of how new businesses to process groundnut in the area have sprouted up. "After seeing that groundnut are now available in large quantities here, we have business people in the business of processing and grinding groundnut."

\subsection{Development Organizations Partnered to Spread Improved Varieties to Communities}

American politician and environmentalist, Mr. Albert Arnold Gore Jr., was once quoted saying, "If you want to go quickly, walk alone but if you want to go far, walk in a team." The team running the TL projects in Tanzania knows this too well, and they have endeavored to involve like-minded people to help spread the uptake of improved groundnut varieties within Tanzania.

One such group that was involved is an NGO known as Masasi High-Quality Farmers' Products. The NGO is located in Masasi District, and Ms. Samia Noel Seif is the manager (Figs. 2.32 and 2.33). We talked to her in March 2018, and she said, "We are dealing with cashew nut and other crops and we have twenty-five groups in Masasi District with a total of 6,118 members. We work with TARI-Naliendele and they have helped us since 2008 by providing us the best groundnut seeds."

She says the improved variety seeds have increased the percentage of groundnut farmers in Masasi District. "We have three varieties; Mnanje, Pendo, and Johari. Farmers mostly prefer Pendo as it grows well and fast; in just three months."

Seif reported more about benefits they got under TL projects. "We received training from TAri-Naliendele on areas like how to space when planting, diseases like aflatoxin that affects groundnut quality and about varieties that tolerate drought. They also buy produce from our farmers and sell them on our behalf, so farmers have a market."

Seif's parting shot can only be put in her own language in the fear of watering down the meaning, "Hizi mbegu za kuboreshwa zimeleta manufaa kama kazi iliyopo shambani imepungua kwa vile wanapanda kwa utaalamu na sasa hawapandi 


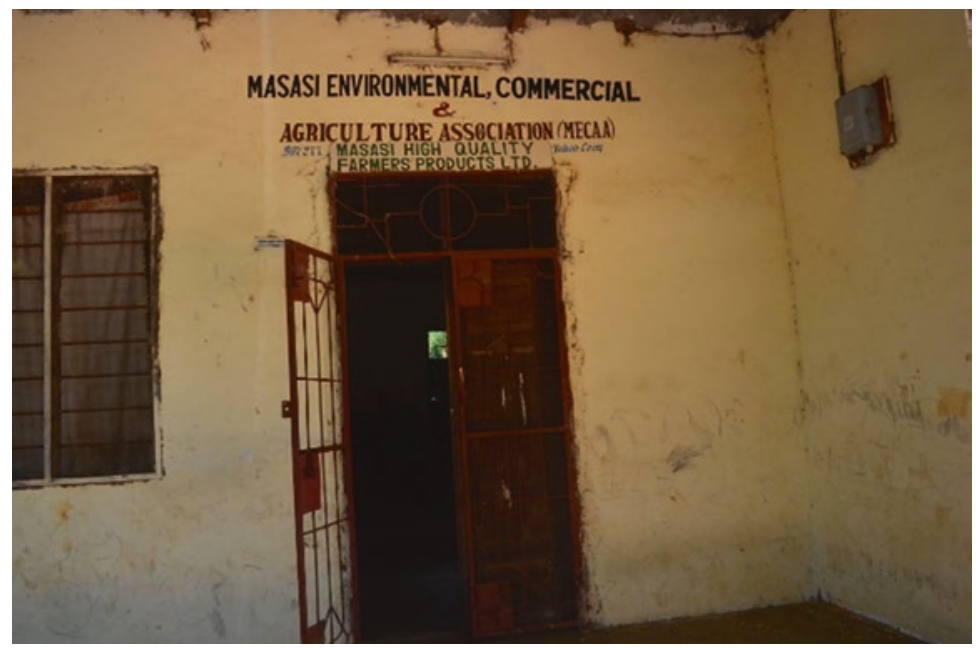

Fig. 2.32 Masasi High-Quality Farmers' Products, Office's establishment in Masasi District, Tanzania (Photo: Ndichu J)

Fig. 2.33 Ms. Samia Noel Seif working at Masasi High-Quality Farmers' Products, Office in Masasi District, Tanzania (Photo: Ndichu J)

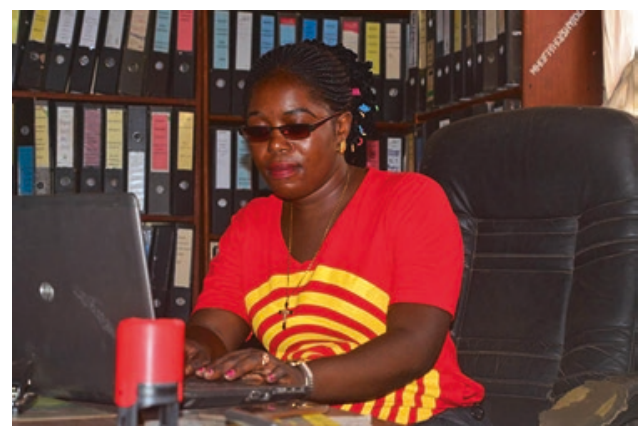

bora mbegu, wanapanda mbegu bora." (These improved variety seed $\mathrm{s}$ have been beneficial as the farmers work less, grow in expertise and are not growing any seeds but better seeds).

\subsection{District Authorities Happy with TL Achievements for Their Farming Communities}

By now, one may wonder whether agricultural leadership was involved. Yes, it was, in the grassroots. We spoke to three District Agriculture, Irrigation and Cooperative Officers, from different agricultural zones, locally known as DAICO in Tanzania. Mr. Aithan Chaula, from Chimwino District, in Dodoma, within the Central Zone (whom we will meet again later speaking in the capacity of a private company seed producer), Mr. Tamba Wilfred from Masasi District in the Southern Zone (Fig. 2.34), 
Fig. 2.34 Mr. Tamba Wilfred talking to visitors at his office in Masasi District. Tanzania (Photo: Ndichu J)
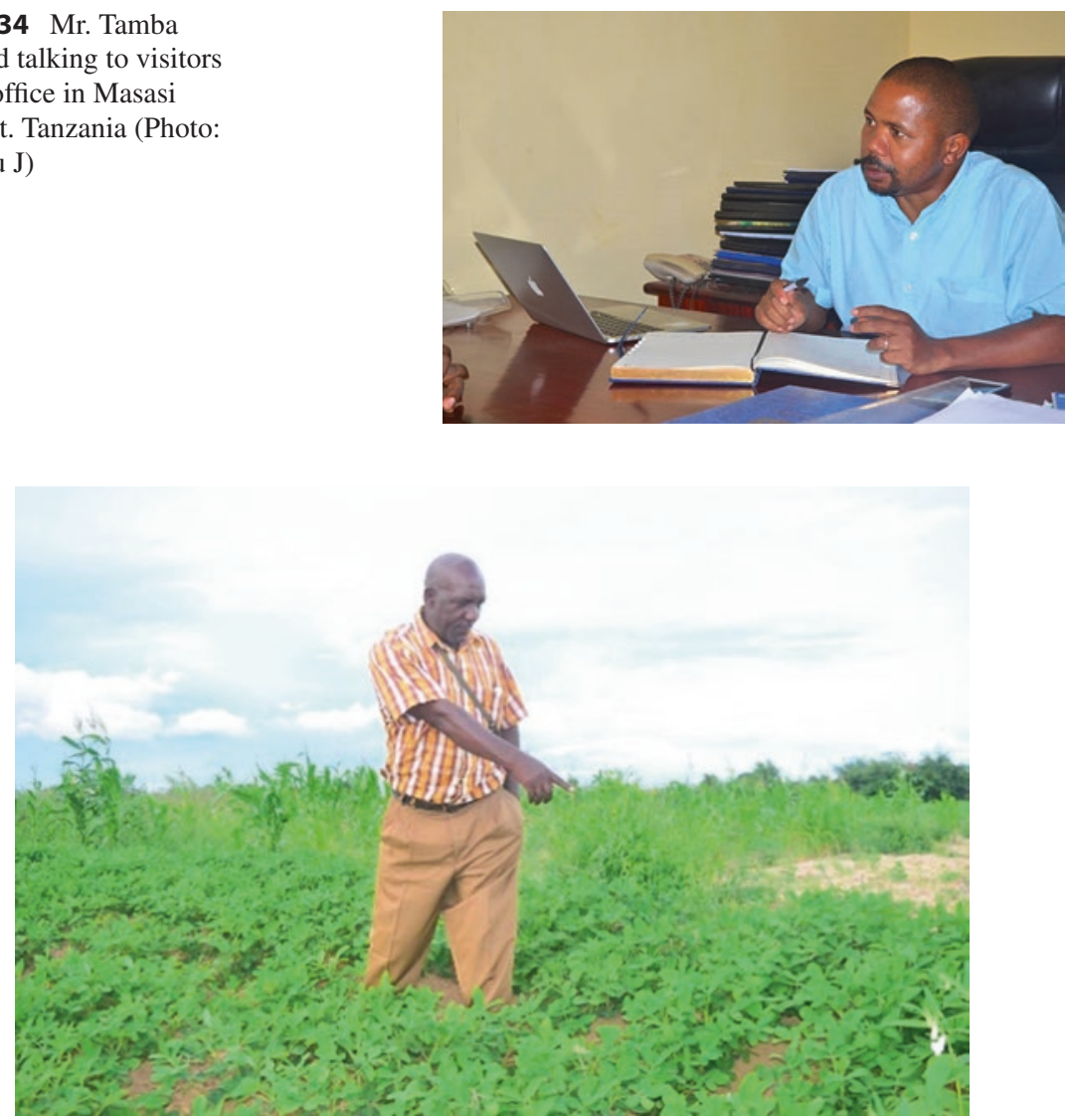

Fig. 2.35 Mr. Aithan Chaula shows us some of the groundnut varieties in his farm in Chimwino District, Dodoma, Tanzania (Photo: Ndichu J)

and Mr. Aron Manguzi from Ushetu District in the Lake Zone. We talked to them between March and April 2018.

They too have all gone through trainings. "We were trained on innovation, mainly in groundnut and beans and how to assist farmers to change from what they are used to and make them view groundnut as a business," says Chaula (Fig. 2.35).

Though from a different region, Tamba shares the same sentiments. "The benefit from this is that groundnut have been taken as serious business with the new improved varieties. But most importantly, production has improved therefore farmers can meet their basic needs from the groundnut production thanks to TL projects," he says. 
Open Access This chapter is licensed under the terms of the Creative Commons Attribution 4.0 International License (http://creativecommons.org/licenses/by/4.0/), which permits use, sharing, adaptation, distribution and reproduction in any medium or format, as long as you give appropriate credit to the original author(s) and the source, provide a link to the Creative Commons licence and indicate if changes were made.

The images or other third party material in this chapter are included in the chapter's Creative Commons licence, unless indicated otherwise in a credit line to the material. If material is not included in the chapter's Creative Commons licence and your intended use is not permitted by statutory regulation or exceeds the permitted use, you will need to obtain permission directly from the copyright holder. 